\title{
Bioactive, Physicochemical and Antimicrobial Properties of Koruk (Unripe Grape, Vitis vinefera L.) Products
}

\begin{abstract}
Berna Öztürk ${ }^{1, a}$, İlkin Yücel Şengün ${ }^{1, b, *}$
${ }^{I}$ Food Engineering Department, Engineering Faculty, Ege University, 35040 Izmir, Turkey *Corresponding author

A R T I C L E I N F O A B T R A C T

Research Article

In the study, the bioactive, physicochemical and antimicrobial properties of koruk juice and dried koruk pomace were investigated. The total phenolic contents of koruk juice and pomace were determined as 1119.670 and $1182.170 \mathrm{mg}$ GAE/L, respectively. Higher DPPH radical scavenging activity found in koruk pomace, which was consistent with total phenolic contents. Organic acid, total sugar and ascorbic acid contents of koruk juice $(3.44 \%, 4.737 \mathrm{~g} / \mathrm{L}$ and $2.559 \mathrm{mg} / 100 \mathrm{~mL}) \mathrm{were}$ higher than koruk pomace $(0.19 \%, 0.866 \mathrm{~g} / \mathrm{L}$ and $0.242 \mathrm{mg} / 100 \mathrm{~mL})$. The counts of Total Psychrophilic Aerobic Bacteria and mold-yeast in pomace were determined as 0.694 and $1.016 \mathrm{log}$ $\mathrm{CFU} / \mathrm{g}$, respectively, while no growth was observed in koruk juice. Koruk juice and pomace indicated antimicrobial effect on all test microorganisms in the range of $31.3-500.0 \mu \mathrm{g} / \mathrm{mL}$ (Minimum Inhibition Concentration). The most sensitive bacteria to koruk juice were Bacillus cereus, while Pediococcus acidilactici was the most sensitive one to koruk pomace. Koruk juice also showed bactericidal effect on all test cultures at concentration ranging between 250.0 and 500.0 $\mu \mathrm{g} / \mathrm{mL}$ (Minimum Bactericidal Concentration), koruk pomace was not showed bactericidal effect on Escherichia coli O157:H7, Salmonella Typhimurium, E. coli and B. cereus. This study demonstrated that the koruk products could be used in food applications as natural antioxidant and antimicrobial substance.

Keywords: Phenolic content Antioxidant Antimicrobial Physical properties
\end{abstract}

|b@ilkin.sengun@ege.edu.tr https://orcid.org/0000-0001-6940-2129

\section{Introduction}

Plants are natural antimicrobial and antioxidant substances and are of great importance for the food industry (Mohammed et al., 2020; Pehlivan et al., 2021). Various plants produce secondary metabolites with antimicrobial properties against many microorganisms and phenolic compounds can exhibit several biological effects associated with antioxidant activities such as antiinflammatory, anticarcinogenic, antiallergic, hepatoprotective and antithrombotic effects (Belletti et al., 2008; Del Rio et al., 2013; Meireles et al., 2016; Sevindik et al., 2017; Vázquez-Armenta et al., 2017; Mohammed et al., 2021).

Unripe grape (Vitis vinifera L.), which contains high amounts of tartaric and malic acids with low sugar content, is usually utilized as acidifier and flavoring agent for several appetizers, salads and dishes (de Matos et al., 2017). It is also known as koruk, koruk juice, verjons, vertjus, verjus, agraz, abe-ghureh, agresto in different countries (Karapinar and Sengun, 2007). Koruk products have high antioxidant and antimicrobial activities due to phenolic compounds of the grapes (Nikfardjam, 2008; Turkmen et al., 2017). The type of fruit, ripening period and environmental conditions are the factors that influence the physicochemical properties of unripe grapes. It has been reported that koruk juice has important benefits on health due to bioactive compounds such as hydroxycinnamic acid, hydroxybenzoic acid, flavonoid and phenolic (Ahmadi and Roney, 2014). It has been determined that the koruk juice has beneficial effects on glycemic control, oxidation, endothelial function, blood pressure and serum lipid profile (Aminian et al., 2003; Endemann and Schiffrin, 2004; Hadi et al., 2005; MoussaAl-Reza et al., 2011; Setorki et al., 2011; Alipour et al., 2012; Zibaeenezhah et al., 2012; Nematbakhsh et al., 2013).

Grape seeds and shells are important sources of phenolic compounds (Bail et al., 2008). There are some natural phenolic antioxidants in grape seed that prevent the oxidation of fats such as tocopherols and tocotrienols (Sabir et al., 2012). During the ripening period, significant 
changes occur in grapes, especially in total acid and phenolic content. In a study conducted by Otag (2015), the titration acidity of the unripe grapes was about 10 times higher than mature grapes. Different researchers have been determined that the total amount of phenolic substances varies depending on the year of production, ripening period, grape variety and grape parts, and the total amount of phenolic substances decreases during ripening period (Doshi et al., 2006; Navarro et al., 2008; Jin et al., 2009).

There is limited knowledge on physical, chemical and microbiological properties of koruk juice and pomace. The aims of this study were to investigate 1) the physical and chemical properties of koruk juice and dried koruk pomace, 2) the potential antibacterial action of koruk products against twelve bacteria (Bacillus cereus No 8, B. subtilis ATCC 6037, Escherichia coli ATCC 1103, E. coli O157:H7 ATCC 43888, E. coli O157:H7 ATCC 43895, Enterococcus faecalis ATCC 29212, Listeria monocytogenes ATCC 49594, L. monocytogenes ATCC 13932, Pediococcus acidilactici ATCC 8042, Staphylococcus aureus 6538P, Salmonella Typhimurium ATCC 13311 and S. Typhimurium ATCC 14028).

\section{Material and Methods}

\section{Preparation of Koruk Products}

Unripe grapes belong to Yediveren variety were taken directly from the grower in Izmir, Turkey. Firstly, grapes were sorted, washed and followed by disinfected for 15 min by vinegar $(5 \%, v / v)$. After rinsing with tap water, the grapes were cut in blender (Waring Commercial Blendor, Waring Product Division New Hartford Conn., USA) at high speed for $1 \mathrm{~min}$. Then the mixture was filtered from cheesecloth and filter paper (Filter-Lab, 40x40 cm), respectively. The obtained liquid (koruk juice) was stored at deep freeze $\left(-18^{\circ} \mathrm{C}\right)$ until analysis. The pomace was dried by using tray dryer (TK Lab Model, Eksis Industrial Drying Systems, Turkey) operated at $60^{\circ} \mathrm{C}$, rate of $1 \mathrm{~m} / \mathrm{s}$ until the moisture content arrives at 3\% (Infrared Moisture Meter, Ohasus MB45 Nanikon, Switzerland) and followed by pulverized. The final product called as dried koruk pomace was stored at $4^{\circ} \mathrm{C}$ after vacuum packing (Henkelman Boxer 42, Holland) (Figure 1).

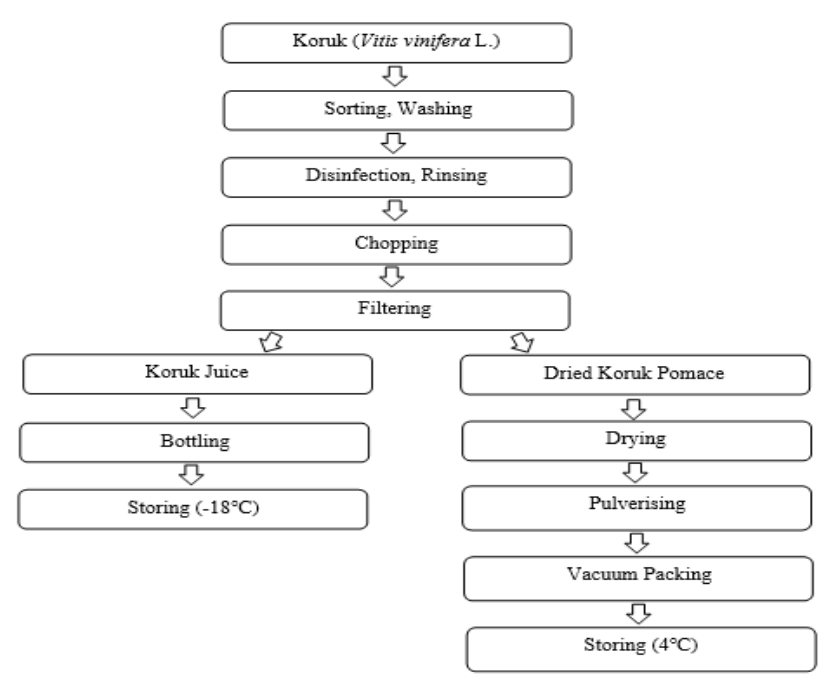

Figure 1. Production flow diagram of Koruk juice and dried Koruk pomace

\section{Extraction of Dried Koruk Pomace}

$100 \mathrm{~g}$ ethanol-water (40:60, v/v) was added to $2 \mathrm{~g}$ dried koruk pomace and incubated at $25^{\circ} \mathrm{C}$ for $24 \mathrm{~h}$ in shaking incubator. Then, sample was centrifugated at $5000 \mathrm{rpm}$ for $25 \mathrm{~min}$ and was dried in a vacuum evaporator at $40^{\circ} \mathrm{C}$ to remove the ethanol (Corrêa et al., 2017).

\section{Microbiological Analyses}

Microbiological analyses were determined using rapid microbiological methods. First dilutions of the samples were prepared using $0.1 \%$ peptone water ( $\mathrm{PW}$, Oxoid, $\mathrm{pH}$ $6.8 \pm 0.2$ ) and followed by homogenized in a Stomacher (Stomacher Lab-Blender 400, Seward Medical, London, UK) for 60 seconds. Serial dilutions were also prepared in 9 $\mathrm{mL}$ of $0.1 \% \mathrm{PW}$. After inoculating TEMPO AC test kits (BioMerieux, Ref. 411113, BioMerieux S.A., France) for counting total mesophilic aerobic bacteria (TMAB) and total psychrophilic aerobic bacteria (TPAB), the cards were incubated at $35^{\circ} \mathrm{C}$ for $24-48 \mathrm{~h}$ and $7^{\circ} \mathrm{C}$ for 12 days (Gilliand et al., 1976; FDA-BAM, 2001a). TEMPO YM test kits (BioMerieux, Ref. 80001, BioMerieux S.A., France) were inoculated for detecting yeast-mold counts and the cards were incubated at $25^{\circ} \mathrm{C}$ for 5 days (FDA-BAM, 2001b).

\section{pH, Total Acidity and Brix Measurement}

The $\mathrm{pH}$ values of the koruk products were measured using a pH meter (Nel Mod 821). The total acidic values of the products were identified using titrimetric method. Results were given as $\mathrm{g} / 100 \mathrm{~mL}$ in tartaric acid. The Brix values of the samples were recorded by a refractometer (Hanna HI 96801) (AOAC, 2007).

\section{Total Sugar Content}

The phenol sulfuric acid method was used for determining the total sugar contents of the samples (Taylor, 1995). $1 \mathrm{~g} / \mathrm{L}$ sample was mixed with $5 \mathrm{~mL}$ of hydrochloric acid $(2.5 \mathrm{~N})$ and the mixture was kept in water bath at $95^{\circ} \mathrm{C}$ for $3 \mathrm{~h}$. After that, the temperature of the sample was reduced to $1^{\circ} \mathrm{C}$ in $5 \mathrm{~min} .750 \mu \mathrm{L}$ sodium hydroxide $(40 \%, \mathrm{w} / \mathrm{v})$ was mixed with the sample and the mixture was completed with distilled water to $100 \mathrm{~mL}$. Then $600 \mu \mathrm{L}$ of the prepared solution was added to $600 \mu \mathrm{L}$ phenol solution $(5 \%, \mathrm{w} / \mathrm{v})$ and $3 \mathrm{~mL}$ sulfuric acid was added to the mixture. The solution was held in water bath at $80^{\circ} \mathrm{C}$ for $30 \mathrm{~min}$. The absorbance was recorded by a spectrophotometer at $490 \mathrm{~nm}$. The total sugar content of the products was calculated by the equation obtained from standard solutions.

\section{Ascorbic Acid Content}

The ascorbic acid contents of the products were determined using a spectrophotometric method at $518 \mathrm{~nm}$ (Hisil, 2004). $1 \mathrm{~mL}$ stabilizer solution was mixed with $9 \mathrm{~mL}$ 2,6-diklorofenolindofenol solution and the absorbance of mixture was measured (L). During the preparation of samples, $90 \mathrm{~mL}$ stabilizer solution was added to $10 \mathrm{~g} / \mathrm{mL}$ of the sample and the mixture was filtered. Then, $9 \mathrm{~mL} \mathrm{2,6-}$ diklorofenolindofenol solution was added to $1 \mathrm{~mL}$ filtered sample and the absorbance of mixture was measured (Ls). The final absorbance values of the samples were determined using following equation:

The final absorbance value: L - Ls

Ascorbic acid concentrations of the products were determined by the equation obtained from the graph and expressed as $\mathrm{mg} / 100 \mathrm{~mL}$. 


\section{Ash Content}

Ash contents of the samples were determined using muffle furnace (Carbolite Gero Ltd., Germany) at $525^{\circ} \mathrm{C}$. Results were expressed as \% (AOAC, 2007).

\section{Color Properties}

The color properties of the samples were determined by HunterLab Colorflex (Management Comp., USA). The results were stated as $L^{*}$ (whiteness/darkness), $a^{*}$ (redness/greenness) and $b^{*}$ (yellowness/blueness) (Kramer and Twigg, 1984).

\section{Total Phenolic Contents}

The Folin-Ciocalteu colorimetric method was used to determine the total phenolic contents of koruk juice and dried koruk pomace. $1 \mathrm{~mL}$ of filtered sample was added to $75 \mathrm{~mL}$ of distilled water, and then $5 \mathrm{~mL}$ of Folin-Ciacalteu reagent was added to the solution. The mixture was held at room temperature in the dark for $3 \mathrm{~min}$. After that, $10 \mathrm{~mL}$ of sodium carbonate solution $(75 \mathrm{~g} / \mathrm{L})$ was added to the reaction mixture, followed by was completed to $100 \mathrm{~mL}$ with distilled water and the mixture was kept at room temperature in the dark for $90 \mathrm{~min}$. The spectrophotometer (Agilent Technologies, Carry60 UV-Visible) was used for determining the absorbance of the solution and the absorbance was measured at $734 \mathrm{~nm}$. Results were stated in mg gallic acid equivalents (GAE)/L (Cemeroğlu, 2013).

\section{Antioxidant Capacity}

The antioxidant activities of the koruk products were analyzed according to DPPH and ABTS radical scavenging methods.

\section{DPPH Radical Scavenging Activity}

DPPH radical scavenging activity of the samples was examined using the modified protocol indicated by Singh et al. (2002). $5 \mathrm{~mL}$ of DPPH solution $(0.1 \mathrm{mM}$ in methanol) was added to $0.1 \mathrm{~mL}$ of filtered sample and the mixture was allowed in the dark at room temperature for $15 \mathrm{~min}$. The absorbance was determined using a spectrophotometer at $517 \mathrm{~nm}$. Methanol was used as control. DPPH radical scavenging activity was calculated using the following equation:

$$
\text { DPPH radical scavenging activity }(\%)=\frac{(\mathrm{Ac}-\mathrm{As})}{\mathrm{Ac}} \times 100
$$

Ac: the absorbance of the control

As: the absorbance of the sample.

\section{ABTS+ Radical Scavenging Activity}

ABTS radical scavenging capacity was also used for determining of antioxidant capacity of samples (Re et al., 1999). $7 \mathrm{mM}$ ABTS+ solution and $2.45 \mathrm{mM}$ ammonium persulfate were used to prepare ABTS+ stock solution. The solution was kept in the dark at room temperature for $16 \mathrm{~h}$. ABTS+ solution was diluted with ethanol to obtain absorbance value of $0.70 \pm 0.02$ at $734 \mathrm{~nm} .3 \mathrm{~mL}$ of ABTS+ solution was added to $0.3 \mathrm{~mL}$ of samples and the mixture was kept in the dark at room temperature for $6 \mathrm{~min}$. The absorbance was measured using a spectrophotometer at 734 $\mathrm{nm}$. Ethanol was used as a blank. ABTS+ radical scavenging capacity was calculated using following equation:
$\mathrm{ABTS}+$ radical scavenging activity $(\%)=\frac{(\mathrm{Ac}-\mathrm{As})}{\mathrm{Ac}} \times 100$

Ac: the absorbance of the control

As: the absorbance of the sample.

\section{Antimicrobial Activity}

The antimicrobial activity of koruk juice and dried koruk pomace extract were examined against Bacillus cereus No 8, B. subtilis ATCC 6037, Escherichia coli ATCC 1103, E. coli O157:H7 ATCC 43888, E. coli O157:H7 ATCC 43895, Enterococcus faecalis ATCC 29212, Listeria monocytogenes ATCC 49594, L. monocytogenes ATCC 13932, Pediococcus acidilactici ATCC 8042, Staphylococcus aureus 6538P, Salmonella Typhimurium ATCC 13311 and S. Typhimurium ATCC 14028), which were obtained from Ege University, Food Engineering Department, Food Microbiology Research Laboratory and Izmir Food Control Laboratory. Activation of stock cultures were performed in Tryptic Soy Broth (TSB, pH 7.3 \pm 0.2 , Oxoid) by incubating at $37^{\circ} \mathrm{C}$ for $24 \mathrm{~h}$. The cultures were optimized equivalent to $0.5 \mathrm{McF}$ arland (DEN-1 McFarland Densitometer, Grant-bio) turbidity standard.

The minimum inhibitory concentration (MIC) of koruk products was determined using microdilution method by 96-well "U" type sterile microplates (Deng et al., 2014). $100 \mu \mathrm{L}$ of Mueller Hinton Broth (MHB, Oxoid, pH $7.3 \pm 0.2$ ) was transferred into every well followed by the addition of koruk juice or dried koruk pomace extract into the wells of the first row. Samples, serially two-fold diluted by MHB were transferred into wells and the final concentrations in the wells were between 1-500 $\mu \mathrm{g} / \mathrm{mL}$. Then, $10 \mu \mathrm{L}$ of inoculum were added to every well and incubation was performed at $37^{\circ} \mathrm{C}$ for $18 \mathrm{~h}$. After that, 20 $\mu \mathrm{L}$ of $0.5 \%$ 2,3,5-triphenyltetrazolium chloride (TTC, Merck) was added to each well and the plates were incubated at $37^{\circ} \mathrm{C}$ for $30 \mathrm{~min}$ for detecting MIC values of the samples. The minimum bactericidal concentration (MBC) of the samples were also detected by streaking samples taken from the first wells, where no growth was observed, on streaking on Mueller-Hilton Agar (MHA, Oxoid, pH 7.3 \pm 0.2 ) (Tomas-Menor et al., 2013).

\section{Statistical Analysis}

Experiments were performed in three replicates. Results were stated as mean \pm standard error. The SPSS 20.0 for Windows Software Package was used to evaluate the experimental data and evaluation was performed (at the significance level of $\mathrm{P} \leq 0.05$ ) by using one-way ANOVA and Duncan multiple comparison methods (SPSS, 2011).

\section{Results and Discussion}

\section{Microbiological and Physicochemical Properties}

TMAB, TPAB, mold and yeast counts were performed to determine the microbiological properties of koruk products (Table 1). TMAB, TPAB and mold-yeast growth was not detected in the koruk juice. TMAB growth was not observed in the dried koruk pomace, while the counts of TPAB and mold-yeast were determined as 0.694 and 1.016 $\log \mathrm{CFU} / \mathrm{g}$, respectively. 
Table 1. The counts of Total Mesophilic Aerobic Bacteria (TMAB), Total Psychrophilic Aerobic Bacteria (TPAB) and yeast-mold of Koruk products

\begin{tabular}{|c|c|c|c|}
\hline Koruk products & TMAB & TPAB & Mold-yeast \\
\hline Koruk juice $(\log \mathrm{CFU} / \mathrm{mL})$ & $-{ }^{*}$ & 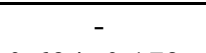 & - \\
\hline Dried Koruk pomace $(\log \mathrm{CFU} / \mathrm{g})$ & - & $0.694 \pm 0.173^{\mathrm{a}}$ & $1.016 \pm 0.919^{\mathrm{b}}$ \\
\hline
\end{tabular}

Table 2. Some physicochemical properties of Koruk products

\begin{tabular}{l|cc}
\multicolumn{1}{c|}{ Analysis } & Koruk juice & Dried Koruk pomace \\
\hline $\mathrm{pH}$ & $2.940 \pm 0.050^{\mathrm{a}}$ & $3.890 \pm 0.068^{\mathrm{b}}$ \\
Total acidity $(\mathrm{g}$ tartaric acid/100 mL) & $3.524 \pm 0.149^{\mathrm{a}}$ & $0.192 \pm 0.005^{\mathrm{b}}$ \\
Brix & $4.233 \pm 0.058^{\mathrm{a}}$ & $11.433 \pm 0.058^{\mathrm{b}}$ \\
Total sugar content $(\mathrm{mg} / 100 \mathrm{~mL})$ & $4.737 \pm 0.131^{\mathrm{a}}$ & $0.866 \pm 0.106^{\mathrm{b}}$ \\
Ascorbic acid content $(\mathrm{mg} / 100 \mathrm{~mL})$ & $2.559 \pm 0.172^{\mathrm{a}}$ & $0.242 \pm 0.04^{\mathrm{b}}$ \\
Ash content $(\%)$ & $0.169 \pm 0.004^{\mathrm{a}}$ & $0.169 \pm 0.005^{\mathrm{a}}$ \\
\hline
\end{tabular}

Values in the same row with different lower case $(a, b)$ are significantly different $(\mathrm{P}<0.05)$.

Table 3. Color properties of Koruk products

\begin{tabular}{l|ccc}
\hline \multicolumn{1}{c|}{ Koruk products } & $L^{*}$ & $a^{*}$ & $b^{*}$ \\
\hline Koruk juice & $0.425 \pm 0.299^{\mathrm{a}}$ & $0.015 \pm 0.006^{\mathrm{a}}$ & $11.075 \pm 0.309^{\mathrm{a}}$ \\
Dried Koruk pomace & $30.635 \pm 0.286^{\mathrm{b}}$ & $36.443 \pm 0.102^{\mathrm{b}}$ & $52.655 \pm 0.328^{\mathrm{b}}$ \\
\hline
\end{tabular}

Values in the same row with different lower case $(a, b)$ are significantly different $(\mathrm{P}<0.05)$.

The $\mathrm{pH}$, total acidity and Brix values of the koruk juice and dried koruk pomace were determined as 2.940-3.890, 3.524-0.192 g tartaric acid/100 mL and 4.233-11.433, respectively $(\mathrm{P}<0.05)$. Chemical properties of grape strongly change depending on growing area, variety, harvesting period and maturity. Hence, the results of the previous studies show differences. In a study, it was determined that the $\mathrm{pH}$ and Brix values of the koruk juice obtained from different types of grapes (Cabernet sauvignon, Chardonnay, Cabernet franc, Merlot, Glera and Sauvignon blanc) ranged between 2.56-2.91 and 3.8-9.9, respectively. The amounts of malic acid in koruk juice obtained from white and red grape varieties found between 10.90-28.62 g/L and 17.64-30.38 g/L, respectively, while the amounts of tartaric acid were determined as 5.51-11.78 $\mathrm{g} / \mathrm{L}$ in the white varieties and $6.25-14.05 \mathrm{~g} / \mathrm{L}$ in the red varieties (de Matos et al., 2017). In another study, pH, total acidity and Brix values of the koruk juices obtained from 8 different grape varieties (Kabarcik, Emir, Narince, Muskat, Sultana, Okuzgozu, Bogazkere, Cabernet Sauvignon) were found ranging between 2.00-2.20, 32.52-49.05 g tartaric acid/L and 4.07-5.97, respectively (Guler and Candemir, 2017). In a study performed by Karapinar and Sengun (2007), it was determined that the $\mathrm{pH}$ and total acidity values of the koruk juices produced by different methods were between 2.44-2.78 and 2.75-2.80 g tartaric acid/100 $\mathrm{mL}$, respectively.

The total sugar contents of the koruk juice and dried koruk pomace were determined as 4.737 and $0.866 \mathrm{~g} / \mathrm{L}$, respectively (Table 2). It is determined that the total sugar content of the dried koruk pomace is lower than the koruk juice $(\mathrm{P}<0.05)$. In a study conducted by Nikfardjam (2008), the total sugar contents of koruk juice were ranged between $0.10 \mathrm{~g} / \mathrm{L}$ and $95.10 \mathrm{~g} / \mathrm{L}$. In another study, the total sugar contents of industrially, in laboratory and traditionally produced verjuice and sour grape sauces were determined ranging between $0.85-13.56 \mathrm{~g} / \mathrm{L}$ and 1.18-17.04 g/L, respectively (Oncul and Karabiyikli, 2015). Studies have shown that the total sugar contents of koruk products show differences depending on the harvesting period, product type, genotypic properties and production methods used.

Ascorbic acid values of the koruk juice and dried koruk pomace were determined as $2.5593 \mathrm{mg} / 100 \mathrm{~mL}$ and 0.2419 $\mathrm{mg} / 100 \mathrm{~mL}$, respectively $(\mathrm{P}<0.05)$ (Table 2). Similarly, the ascorbic acid value of koruk juice was determined as 1.8 $\mathrm{mg} / 100 \mathrm{~mL}$ (Setorki et al., 2011). In another study, ascorbic acid contents of koruk products were ranged between 0.00 and $5.91 \mathrm{mg} / 100 \mathrm{~mL}$ (Oncul, 2016).

The amount of ash shows inorganic substances that remain unburned. It was determined that the amounts of ash of koruk juice and dried koruk pomace were $0.169 \%$ and $0.169 \%$, respectively (Table 2). In another study, the amounts of ash of koruk juices obtained from two different varieties (Yediveren and Kabarcik) were determined as $0.244 \%$ and $0.382 \%$, respectively (Hayoglu et al., 2009).

\section{Color Properties}

The color characteristics of koruk products were determined by $L^{*}, a^{*}, b^{*}$ values. $L^{*}, a^{*}$ and $b^{*}$ values of koruk juice were determined as $0.425,0.015$ and 11.075, while $L^{*}, a^{*}, b^{*}$ values of dried koruk pomace were found as $30.635,36.443$ and 52.655 , respectively (Table 3 ). In a study conducted by Oncul (2016), it was determined that, $L^{*}, a^{*}$ and $b^{*}$ values of koruk products were ranged between 32.97-96.57, -9.31-16.38 and -23.52-127.40, respectively. These results showed that color characteristics change depending on the raw materials and production methods used.

\section{Total Phenolic Contents}

The total phenolic contents of koruk juice and dried koruk pomace extract were found as 1119.670 and $1182.170 \mathrm{mg} \mathrm{GAE} / \mathrm{L}$ (Table 4). In a study performed by Guler and Candemir (2017), it was determined that the total phenolic contents of the koruk juices obtained from eight different varieties (Kabarcik, Emir, Narince, Muskat, Sultana, Okuzgozu, Bogazkere, Cabernet Sauvignon) were between 152.11 and $317.71 \mathrm{mg}$ GAE/L. In a study 
conducted by Hayoglu et al. (2009), the total phenolic contents of koruk juice samples were ranged between 6262.7 and $7538.0 \mathrm{mg} \mathrm{GAE} / \mathrm{L}$. In a study, it was determined that the total phenolic contents of koruk juice and sour grape sauce ranged between 233.44-672.75 $\mathrm{mg} / \mathrm{L}$ and 96.79-652.14 $\mathrm{mg} / \mathrm{L}$ respectively (Oncul and Karabiyikli, 2015). Total phenolic contents of the koruk products (unripe grape piece, powder and juice), which were extracted separately with $10 \%$ ethanol and water, were observed in the range of 505.682-758.523 $\mathrm{mg} \mathrm{GAE} / \mathrm{g}$ and 424.432-603.409 mg $\mathrm{GAE} / \mathrm{g}$, respectively (Turkmen et al., 2017). The total phenolic contents of unripe grape marc (Yediveren and Kabarcik varieties) extracts produced using different temperatures $\left(25-50^{\circ} \mathrm{C}\right.$ ), solvent ratios (ethanol/water, 0$100 \%)$ and times (1-24 h) were ranged between 85.60$405.42 \mathrm{mg} \mathrm{GAE} / 100 \mathrm{~g}$ (Shojaee-Aliabadi et al., 2013). In a study performed by Golmakani et al. (2017), lower total phenolic content of koruk marc extract was reported as 49.3 mg GAE/g. It has been reported that the differences in the total phenolic content of koruk products vary according to production year, ripening period and grape variety (Doshi et al., 2006; Navarro et al., 2008; Jin et al., 2009).

\section{Antioxidant Activity}

Different analytical methods are used for determining the antioxidant capacity of foods (Buyuktuncel, 2013; Ray et al., 2018). In this study, two different methods (DPPH and ABTS* radical scavenging assays) were used to determine the antioxidant activities of koruk products. Koruk juice and dried koruk pomace extract inhibited DPPH radical by $90.70 \%$ and $93.32 \%$, respectively $(\mathrm{P}>0.05)$ (Table 4). ABTS* values of koruk juice and dried koruk pomace extract were determined as 1.202 and 0.425 $\mu \mathrm{mol} \mathrm{TE} / \mathrm{mL}$, respectively $(\mathrm{P}<0.05)$. In a study conducted by Oncul and Karabiyikli (2015), the antioxidant capacities of the koruk juice and sour grape sauce were examined by TEAC and FRAP methods. The TEAC results were ranged between $0.035-0.860$ and $0.070-0.885 \mu \mathrm{mol} \mathrm{TE} / \mathrm{mL}$, while the FRAP results were determined between 0.010-0.185 and $0.025-0.231 \mu \mathrm{mol} \mathrm{TE} / \mathrm{mL}$ respectively. In another study, antioxidant activities of koruk juices produced from eight different grape varieties (Kabarcik, Emir, Narince, Muskat, Sultana, Okuzgozu, Bogazkere, Cabernet Sauvignon) were determined between 1.36 and $4.04 \mathrm{mg}$ $\mathrm{DPPH} / \mathrm{mL}$. Koruk juice produced from Okuzgozu variety has the highest antioxidant properties, while the koruk juice of Sultana variety has the lowest antioxidant activity (Guler and Candemir, 2017). In another study, it has been determined that the unripe grape marc inhibits DPPH radical in the range of $47.19 \%$ to $92.21 \%$ (ShojaeeAliabadi et al., 2013). In another study conducted by Golmakani et al. (2017), it has been determined that the extract of unripe grape marc has an effective and rapid interaction with the DPPH radical and the IC50 value is determined as $0.3 \mathrm{mg} / \mathrm{mL}$. The results showed that the antioxidant capacities of the samples may change according to the method used, grape variety and product.

\section{Antimicrobial Activity}

Koruk products show antimicrobial effects as well as antioxidant activity due to acidic characteristics and phenolic compounds in the structure (Turkmen at al., 2017; Ozturk and Sengun, 2019). Antimicrobial activities of koruk products were examined against twelve strains according to broth dilution method. The MIC values of koruk juice ranged between 31.3 and $125.0 \mu \mathrm{g} / \mathrm{mL}$ depending on test cultures (Table 5). B. cereus No 8 was the most sensitive bacteria against koruk juice. When the MIC values determined for different microorganisms were compared, it was observed that the koruk juice was more effective than dried koruk pomace extract against tested microorganisms except $P$. acidilactici ATCC 8042. The MIC values of dried koruk pomace extract were determined in the range of 31.3 and $500.0 \mu \mathrm{g} / \mathrm{mL}$, and the most sensitive microorganism was determined as $P$. acidilactici ATCC 8042 (Table 5).

Table 4. Total phenolic content and antioxidant activity of Koruk products

\begin{tabular}{|c|c|c|c|}
\hline \multicolumn{2}{|c|}{ Analysis } & Koruk juice & Dried Koruk pomace \\
\hline \multicolumn{2}{|c|}{ Total phenolic content (mg GAE/L) } & $1119.670 \pm 108.3^{\mathrm{a}}$ & $1182.170 \pm 56.684^{\mathrm{a}}$ \\
\hline Antioxidant activity & $\begin{array}{c}\text { DPPH }(\%) \\
\text { ABTS }(\mu \mathrm{mol} \mathrm{TE} / \mathrm{mL})\end{array}$ & $\begin{array}{c}90.700 \pm 1.368^{\mathrm{a}} \\
1.202 \pm 0.063^{\mathrm{a}}\end{array}$ & $\begin{array}{l}93.320 \pm 0.134^{\mathrm{a}} \\
0.425 \pm 0.037^{\mathrm{b}}\end{array}$ \\
\hline
\end{tabular}

Values in the same row with different lower case $(a, b)$ are significantly different $(\mathrm{P}<0.05)$.

Table 5. MIC and MBC values of Koruk products against test microorganisms $(\mu \mathrm{g} / \mathrm{mL})$

\begin{tabular}{|c|c|c|c|c|}
\hline \multirow{2}{*}{ Microorganisms } & \multicolumn{2}{|c|}{ Koruk juice } & \multicolumn{2}{|c|}{ Dried Koruk pomace } \\
\hline & MIC & $\mathrm{MBC}$ & MIC & $\mathrm{MBC}$ \\
\hline B. cereus No 8 & 31.3 & 500.0 & 62.5 & $>500.0$ \\
\hline B. subtilis ATCC 6037 & 125.0 & 500.0 & 250.0 & 500.0 \\
\hline E. coli ATCC 1103 & 62.5 & 500.0 & 500.0 & $>500.0$ \\
\hline E. coli $\mathrm{O} 157: \mathrm{H} 7$ ATCC 43888 & 62.5 & 500.0 & 125.0 & $>500.0$ \\
\hline E. coli $\mathrm{O} 157: \mathrm{H} 7$ ATCC 43895 & 125.0 & 500.0 & 250.0 & $>500.0$ \\
\hline E. faecalis ATCC 29212 & 62.5 & 500.0 & 125.0 & 500.0 \\
\hline L. monocytogenes ATCC 13932 & 62.5 & 250.0 & 125.0 & 250.0 \\
\hline L. monocytogenes ATCC 49594 & 62.5 & 250.0 & 125.0 & 500.0 \\
\hline P. acidilactici ATCC 8042 & 62.5 & 250.0 & 31.3 & 500.0 \\
\hline S. aureus $6538 \mathrm{P}$ & 125.0 & 250.0 & 250.0 & 500.0 \\
\hline S. Typhimurium ATCC 13311 & 125.0 & 500.0 & 250.0 & $>500.0$ \\
\hline S. Typhimurium ATCC 14028 & 125.0 & 500.0 & 250.0 & $>500.0$ \\
\hline
\end{tabular}


The koruk juice showed a bactericidal effect at concentrations ranging from 250.0 to $500.0 \mu \mathrm{g} / \mathrm{mL}$ against all tested microorganisms (Table 5). MBC values of dried koruk pomace were determined as $500.0 \mu \mathrm{g} / \mathrm{mL}$ against $B$. subtilis, E. feacalis, L. monocytogenes ATCC 49594, $P$. acidilactici and $S$. aureus, while it was $250.0 \mu \mathrm{g} / \mathrm{mL}$ against L. monocytogenes ATCC 13932. The extract of dried koruk pomace did not show bactericidal effect at concentration under $500.0 \mu \mathrm{g} / \mathrm{mL}$ against other test cultures (B. cereus, E. coli ATCC 1103, E. coli O157:H7 ATCC 43888, E. coli O157:H7 ATCC 43895, S. Typhimurium ATCC 13311 and $S$. Typhimurium ATCC 14028).

The studies on the antimicrobial effect of koruk products are limited. In a study performed by Karabiyikli and Oncul (2015), koruk juice showed inhibitive effect on various microorganisms (B. cereus, E. coli, L. monocytogenes, $S$. aureus and $S$. Typhimurium) at concentration ranging from $6.25 \%$ to $50 \%$ and the most sensitive microorganism was found as $B$. cereus, while the most resistant bacteria was determined as $S$. Typhimurium. In another study, the antimicrobial effect of unripe grape marc extract was investigated against Candida spp., Tricophyton mentagrophytes, T. rubrum, Microsporum gypseum. The MIC values of the extracts were found between 53.58$214.31 \mu \mathrm{g} / \mathrm{mL}$ against Candida strains, while the MIC values were determined between 43.54-133.20 $\mu \mathrm{g} / \mathrm{mL}$ against other test cultures (Simonetti et al., 2017).

\section{Conclusions}

The results of this study demonstrated that koruk juice and dried koruk pomace have high antioxidant and antimicrobial properties. Antimicrobial activity of koruk juice was higher than the extract of dried koruk pomace. This result could be linked with the higher amount of total acidic content of koruk juice than dried koruk pomace. However, the antimicrobial effects of koruk products are not only related to the total acidity, phenolic contents of the product have also an important contribution to the antimicrobial properties. According to the results of this study, waste assessment can be provided with the use of dried koruk pomace, which could be an important contribution to the food industry. Besides, it can be used as a low-cost natural antioxidant source in foods. Further studies including food applications of koruk products that show high antimicrobial and antioxidant activities are needed.

\section{Acknowledgment}

The authors are grateful for the financial support provided for the project entitled "Usage of Koruk Products (Koruk Juice and Dried Koruk Pomace) in Meat Technology for Increasing Product Safety and Developing Healthy Product Formulation" under project no: 1170937 by the Scientific and Technological Research Council of Turkey (TUBITAK).

\section{References}

Ahmadi L, Roney SK. 2014. Pharmacological and phytochemical properties of unripe grape juice (verjuice): A review. Austin Journal of Nutrition and Metabolism, 1(2): 9.
Alipour M, Davoudi P, Davoudi Z. 2012. Effects of unripe grape juice (verjuice) on plasma lipid profile, blood pressure, malondialdehyde and total antioxidant capacity in normal, hyperlipidemic and hyperlipidemic with hypertensive human volunteers. Journal of Medicinal Plants Research, 6: 56775683. doi.org/10.5897/JMPR11-1146

Aminian B, Massoompour SM, Sadeghalvaad A, Omrani GH. 2003. Unripe grape juice (verjuice) as a lipid lowering agent: fact or fiction. Archives of Iranian Medicine, 6: 32-34.

AOAC, 2007. Official Methods of Analysis of the Association of Official Analytical Chemists. 18th edition, AOAC International, USA, 326.

Bail S, Stuebiger F, Krist S, Unterweger H, Buchbauer G. 2008. Characterisation of various grape seed oils by volatile compounds, triacylglycerol composition, total phenols and antioxidant capacity. Food Chemistry, 108: 1122-1132. doi.org/10.1016/j.foodchem.2007.11.063

Belletti N, Lanciotti R, Patrignani F, Gardini F. 2008. Antimicrobial efficacy of citron essential oil on spoilage and pathogenic microorganisms in fruit-based salads. Journal of Food Science, 73(7): M331-M338. doi.org/10.1111/j.17503841.2008.00866.x

Buyuktuncel E. 2013. Main spectrophotometric methods for the determination of total phenolic content and antioxidant activity. Marmara Pharmaceutical Journal, 17: 93-103.

Cemeroglu B. 2013. Food Analysis. Ankara: Food Technology Association Publications. ISBN 9786056341939.

Corrêa RC, Haminiuk CW, Barros L, Dias MI, Calhelha RC, Kato CG, Correa VG, Peralta RM, Ferreira IC. 2017. Stability and biological activity of Merlot (Vitis vinifera) grape pomace phytochemicals after simulated in vitro gastrointestinal digestion and colonic fermentation. Journal of Functional Foods, 36: 410-417. doi.org/10.1016/j.jff.2017.07.030

De Matos AD, Curioni A, Bakalinsky AT, Marangon M, Pasini G, Vincenzi S. 2017. Chemical and sensory analysis of verjuice: an acidic food ingredient obtained from unripe grape berries. Innovative Food Science and Emerging Technologies, 44: 9-14. doi.org/10.1016/j.ifset.2017.09.014

Del Rio D, Rodriguez-Mateos A, Spencer JP, Tognolini M, Borges G, Crozier A. 2013. Dietary (poly) phenolics in human health: structures, bioavailability, and evidence of protective effects against chronic diseases. Antioxidants and Redox Signaling, 18(14): 1818-1892. doi.org/10.1089/ ars.2012.4581

Deng Y, Yang G, Yue J, Qian B, Liu Z, Wang D, Zhong Y, Zhao Y. 2014. Influences of ripening stages and extracting solvents on the polyphenolic compounds, antimicrobial and antioxidant activities of blueberry leaf extracts. Food Control, 38: 184-191. doi.org/10.1016/j.foodcont.2013.10.023

Doshi P, Adsule P, Banerjee K. 2006. Phenolic composition and antioxidant activity in grapevine parts and berries (Vitis vinifera L.) cv. Kishmish Chornyi (Sharad Seedless) during maturation. International Journal of Food Science and Technology, 41(1): 19 . doi.org/10.1111/j.13652621.2006.01214.x

Endemann DH, Schiffrin EL. 2004. Endothelial dysfunction. Journal of the American Society of Nephrology, 15: 1983-1992.

FDA-BAM (Food and Drug Administration-Bacteriological Analytical Manual), 2001a. Aerobic Plate Count. Available from: https://www.fda.gov/food/foodscienceresearch/labora torymethods/ucm063346.htm [Accessed 25 July 2017]

FDA-BAM (Food and Drug Administration-Bacteriological Analytical Manual, 2001b. Yeasts, Molds and Mycotoxins. Available from: https://www.fda.gov/Food/FoodScience Research/LaboratoryMethods/ucm071435.htm [Accessed 25 July 2017]

Gilliand SE, Michener HD, Kraft AA. 1976. "Psychrotrophic microorganisms" in compendium of methods for the microbiological examination of food. Washington: American Public Health Association. 
Golmakani MT, Keramat M, Moosavi-Nasab M, Moosavian B. 2017. Oxidative stability of common kilka (Clupeonella cultriventris caspia) oil supplemented with microwave extracted Ghure (unripe grape) marc extract. Journal of Aquatic Food Product Technology, 26(9): 1022-1031. doi.org/10.1080/10498850.2017.1375589

Guler A, Candemir A. 2017. Polyphenol contents, antioxidant activities, colour and chemical properties of fresh koruk (sour grape) juices in Turkey. In: Proceedings of International Balkan Agriculture Congress Book; Tekirdağ, Turkey. pp. 679-684.

Hadi HA, Carr CS, Al Suwaidi J. 2005. Endothelial dysfunction: cardiovascular risk factors, therapy, and outcome. Vascular Health and Risk Management, 1: 183-198.

Hayoglu I, Kola O, Kaya C, Ozer S, Turkoglu H. 2009. Chemical and sensory properties of verjuice, a traditional turkish nonfermented beverage from kabarcik and yediveren grapes. Journal of Food Processing and Preservation, 33(1): 252-263. doi.org/10.1111/j.1745-4549.2008.00339.x

Hisil Y. 2004. Instrumental food analysis - Laboratory experiments, Ege University, Faculty of Engineering, Izmir.

Jin ZM, He JJ, Bi HQ, Cui XY, Duan CQ. 2009. Phenolic compound profiles in berry skins from nine red wine grape cultivars in Northwest China. Molecules, 14(12): 4922-4935. doi.org/10.3390/molecules 14124922

Karabiyikli S, Oncul N. 2015. Inhibitory effect of unripe grape products on foodborne pathogens. Journal of Food Processing and Preservation, 40(6): 1459-1465. doi.org/10.1111/ jfpp. 12731

Karapinar M, Sengun IY. 2007. Antimicrobial effect of koruk (unripe grape - Vitis vinifera) juice against Salmonella Typhimurium on salad vegetables. Food Control, 18: 702706. doi.org/10.1016/j.foodcont.2006.03.004

Kramer A, Twigg BA. 1984. Quality Control for the Food Industry (Vol.1). Wesport: The Avi Publishing Company.

Meireles A, Giaouris E, Simões M. 2016. Alternative disinfection methods to chlorine for use in the fresh-cut industry. Food Research International, 82: 71-85. doi.org/10.1016/ j.foodres.2016.01.021

Mohammed FS, Kina E, Sevindik M, Dogan M, Pehlivan M. 2021. Datura stramonium (Solanaceae): Antioxidant and Antimicrobial Potentials. Turkish Journal of AgricultureFood Science and Technology, 9(4): 818-821.

Mohammed FS, Şabik AE, Doğan M, Selamoğlu Z, Sevindik M. 2020. Antioxidant potential of Hypericum spectabile JAUB. ET SPACH. Bulletin of Biotechnology, 1(2): 43-45.

Moussa-Al-Reza H, Ziba R, Zakieh K, Rad Tania S, MohammadMahdi S. 2011. The Effect of verjuice on serum lipid levels in mice rendered atherosclerosis. Journal of Biologically Active Products from Nature, 1: 229-235. doi.org/10.1080/ 22311866.2011.10719090

Navarro S, Leon M, Roca-Perez L, Boluda R, Garcia-Ferriz L, Perez- Bermu'dez P, Gavidia I. 2008. Characterisation of Bobal and Crujidera grape cultivars, in comparison with Tempranillo and Cabernet Sauvignon: Evolution of leaf macronutrients and berry composition during grape ripening. Food Chemistry, 108: 182-190. doi.org/10.1016/j.foodchem. 2007.10.060

Nematbakhsh M, Zolfaghari B, Eshraghi F, Safari T, Pezeshki Z, Sorooshzadeh SM. 2013. The effects of unripe grape extract on systemic blood pressure, nitric oxide production, and response to angiotensin II administration. Pharmacognosy Research, 5: 60-64. doi: 10.4103/0974-8490.110511

Nikfardjam MSP. 2008. General and polyphenolic composition of unripe grape juice (verjus/verjuice) from various producers. Mitteilungen Klosterneuburg Rebe und Wein Obstbau und Fruchteverwertung, 58: 28-31.

Oncul N. 2016. Determination of antimicrobial and antioxidant properties of unripe grape (Vitis vinifera) products. Doctorate Thesis, Gaziosmanpasa University, Graduate School of Natural and Aplied Sciences, Department of Food Engineering, 179p.
Oncul N, Karabiyikli S. 2015. Factors affecting the quality attributes of unripe grape functional food products. Journal of Food Biochemistry, 39(6): 689-695. doi.org/10.1111/jfbc. 12175

Otag MR. 2015. Determination of some properties and resveratrol content of some grape varieties grown in denizli çal region during different ripening period and after drying process. Doctorate Thesis, Pamukkale University, Denizli.

Ozturk B, Sengun IY. 2019. Inactivation effect of marination liquids prepared with koruk juice and dried koruk pomace on Salmonella Typhimurium, Escherichia coli O157:H7 and Listeria monocytogenes inoculated on meat. International Journal of Foof Microbiology, 304: 32-38. doi.org/ 10.1016/j.ijfoodmicro.2019.05.013

Pehlivan M, Mohammed FS, Şabik AE, Kına E, Dogan M, Yumrutaş Ö, Sevindik M. 2021. Some Biological activities of ethanol extract of Marrubium globosum. Turkish Journal of Agriculture-Food Science and Technology, 9(6): 1129-1132.

Ray A, Jena S, Dash B, Kar B, Halder T, Chatterjee T, Ghosh B, Panda PC, Nayak S, Mahapatra N. 2018. Chemical diversity, antioxidant and antimicrobial activities of the essential oils from Indian populations of Hedychium coronarium Koen. Industrial Crops and Products, 112: 353-362. doi.org/ 10.1016/j.indcrop.2017.12.033

Re R, Pellegrini N, Proteggente A, Pannala A, Yang M, RiceEvans C. 1999. Antioxidant activity applying an improved ABTS radical cation decolarization assay. Free Radical Biology and Medicine, 26: 1231-1237. doi.org/ 10.1016/S0891-5849(98)00315-3

Sabir A, Unver A, Kara Z. 2012. The fatty acid and tocopherol constituents of the seed oil extracted from 21 grape varieties (Vitis spp.). Journal of the Science of Food and Agriculture, 92: 1982-1987. doi.org/10.1002/jsfa.5571

Setorki M, Nazari B, Asgary S, Azadbakht L, Rafieian-Kopaei M. 2011. Anti-atherosclerotic effects of verjuice on hypocholesterolemic rabbits. African Journal of Pharmacy and Pharmacology, 5: 1038-1045.

Sevindik M, Akgul H, Pehlivan M, Selamoglu Z. 2017. Determination of therapeutic potential of Mentha longifolia ssp. longifolia. Fresen Environ Bull, 26(7): 4757-4763.

Simonetti G, D'Auria FD, Mulinacci N, Milella RA, Antonacci D, Innocenti M, Pasqua G. 2017. Phenolic content and in vitro antifungal activity of unripe grape extracts from agroindustrial wastes. Natural Product Research, 1-5. doi.org/10.1080/14786419.2017.1410811

Singh RP, Chidambara Murthy KN, Jayaprakasha GK. 2002. Studies on antioxidant activity of pomegranate (Punica granatum) peel extract using in vivo models. Journal of Agricultural and Food Chemistry, 50(17): 4791-4795. doi.org/10.1021/jf010865b

Shojaee-Aliabadi S, Hosseini SM, Tiwari B, Hashemi M, Fadavi G, Khaksar R. 2013. Polyphenols content and antioxidant activity of Ghure (unripe grape) marc extract: influence of extraction time, temperature and solvent type. International Journal of Food Science and Technology, 48(2): 412-418. doi.org/10.1111/j.1365-2621.2012.03203.x

SPSS, 2011. Statistical Package, SPSS for Windows, Ver. 20.0, Chicago.

Taylor KACC. 1995. A modification of the phenol/sulfuric acid assay for total carbohydrates giving more comparable absorbances. Applied Biochemistry and Biotechology, 53(3): 207-214.

Tomas-Menor L, Morales-Soto A, Barrajón-Catalán E, RoldánSegura C, Segura-Carretero A, Micol V. 2013. Correlation between the antibacterial activity and the composition of extracts derived from various Spanish Cistus species. Food and Chemical Toxicology, 55: 313-322. doi.org/10.1016/j.fct.2013.01.006

Turkmen FU, Takci HAM, Sekeroglu N. 2017. Total phenolic and flavonoid contents, antioxidant and antimicrobial activities of traditional unripe grape products. Indian Journal of Pharmaceutical Education and Research, 51(3): 489-493. doi.org/10.5530/ijper.51.3s.72 
Vázquez-Armenta FJ, Silva-Espinoza BA, Cruz-Valenzuela MR, González-Aguilar GA, Nazzaro F, Fratianni F, Ayala-Zavala JF. 2017. Antibacterial and antioxidant properties of grape stem extract applied as disinfectant in fresh leafy vegetables. Journal of Food Science and Technology, 54(10): 3192-3200.
Zibaeenezhad MJ, Mohammadi E, Babaie Beigi MA, Mirzamohammadi F, Salehi O. 2012. The effects of unripe grape juice on lipid profile improvement. Cholesterol, 3. doi:10.1155/2012/890262 